\title{
Cellulases and xylanases production by endophytic fungi by solid state fermentation using lignocellulosic substrates and enzymatic saccharification of pretreated sugarcane bagasse
}

\author{
Natália Paganini Marques ${ }^{\mathrm{a}}$, Josiani de Cassia Pereira ${ }^{\mathrm{b}}$, Eleni Gomes ${ }^{\mathrm{b}}$, Roberto da Silva ${ }^{\mathrm{c}}$, \\ Angela Regina Araújo ${ }^{\mathrm{d}}$, Henrique Ferreira ${ }^{\mathrm{e}}$, André Rodrigues ${ }^{\mathrm{e}}$, Kelly Johana Dussán ${ }^{\mathrm{a}}$, \\ Daniela Alonso Bocchini ${ }^{\text {a,* }}$ \\ a Department of Biochemistry and Chemical Technology, IQ/UNESP-Univ Estadual Paulista, Rua Prof. Francisco Degni, 55, 14800-060 Araraquara, São Paulo State, \\ Brazil \\ ${ }^{\mathrm{b}}$ Department of Biology, IBILCE/UNESP-Univ Estadual Paulista, Rua Cristóvão Colombo, 2265, 15054-000 São José do Rio Preto, São Paulo State, Brazil \\ ${ }^{\mathrm{c}}$ Department of Chemistry and Environmental Sciences, IBILCE/UNESP - Univ Estadual Paulista, Rua Cristóvão Colombo, 2265, 15054-000 São José do Rio Preto, São \\ Paulo State, Brazil \\ d Department of Organic Chemistry, IQ/UNESP-Univ Estadual Paulista, Rua Prof. Francisco Degni, 55, 14800-060 Araraquara, São Paulo State, Brazil \\ e Department of Biochemistry and Microbiology, IB/UNESP-Univ Estadual Paulista, Avenida 24A, 1515, 13506-900, Rio Claro, São Paulo State, Brazil
}

\section{A R T I C L E I N F O}

\section{Keywords:}

Endophytic fungi

Solid state fermentation

Cellulases

Xylanases

Sugarcane bagasse saccharification

\begin{abstract}
A B S T R A C T
Endophytic fungi are widely studied as producers of secondary metabolites of biotechnological interest. In recent years, the interest in these fungi as new sources of enzymes, especially hydrolytic, has increased. In the present study, 14 strains of endophytic fungi not yet explored as enzymes sources were randomly chosen and prospected for cellulases and xylanases production by solid-state fermentation. Initially, fungi were cultivated in a mixture $(1: 1 \mathrm{w} / \mathrm{w})$ of sugarcane bagasse and wheat bran for 7 days, at $28^{\circ} \mathrm{C}$. In this initial screening, 4 fungi excelled in endoglucanase activity (U/g): Cladosporium cladosporioides PAJ $03(88.51 \pm 1.0)$, Phomopsis stipata SC 04 (83.44 \pm 7.7), Trichoderma viridae PAJ 01 (64.56 \pm 4.0$)$ and Botryosphaeria sp. AM 01 (42.79 \pm 1.6$)$. On the other hand, the following 4 fungi stood out in relation to $\beta$-glucosidase activity (U/g): Saccharicola sp. EJC 04 (51.56 \pm 2.7), Paecilomyces sp. SF 021 (33.19 \pm 9.2), Ustilaginoidea sp. CV 04 (29.75 \pm 0.8 ) and Ustilaginoidea sp. XYA $04(21.72 \pm 3.05)$. Among these fungi, P. stipata SC 04 and Botryosphaeria sp. AM 01 were the best producers of xylanase and $\beta$-xilosidase $(694,33$ and 4,87 $\mathrm{U} / \mathrm{g}$, respectively). These 8 fungi were then cultured in new mixtures $(1: 1 \mathrm{w} / \mathrm{w})$ of lignocellulosic substrates. Botryosphaeria sp. AM01and Saccharicola sp. EJC04 stood out regarding endoglucanase and $\beta$-glucosidase activities $(184.74 \pm 6.0$ and $92.28 \pm 9.57 \mathrm{U} / \mathrm{g}$, respectively) when cultivated on cotton seed meal and wheat bran and were selected to continue the study. The influence of time cultivation, inoculum amount and substrate initial moisture content was evaluated and the best condition for cellulases production was $192 \mathrm{~h}$, six mycelial plugs and $65 \%$, respectively, for both fungi. Cellulases and xylanases produced under these conditions were characterized and optimum pH and temperature values were between $4.5-6$ and $60-75^{\circ} \mathrm{C}$, respectively. The enzymes were stable over a wide $\mathrm{pH}$ range and under $30-70{ }^{\circ} \mathrm{C}$. $\beta$-glucosidase from both isolates retained about $75-80 \%$ of their activity in the presence of glucose at $6 \mathrm{mM}$. The presence of ethanol stimulated $\beta$-glucosidase activity from Botryosphaeria sp. AM01 (about $60 \%$ higher in the presence of ethanol at 15\%). On the other hand, the activity of $\beta$-glucosidase produced by Saccharicola sp. EJC 04 was reduced at ethanol concentrations above 15\%. A blend of the enzymatic extracts was used to saccharify pretreated sugarcane bagasse and a face-centered central composite design was used to find the best conditions. Under the predicted optimum condition $\left(50{ }^{\circ} \mathrm{C}, 5 \%\right.$ of sugarcane bagasse, $150 \mathrm{U} \mathrm{g}^{-1}$ of endoglucanase and $20 \mathrm{~h}$ ), glucose and xylose concentrations obtained were 3.56 and $1.66 \mathrm{mg} \mathrm{mL}^{-1}$, respectively. These results show that the 14 endophytic fungi studied have potential to be explored as producers of plant material degrading enzymes. Botryosphaeria sp. AM01 and Saccharicola sp. EJC 04 are promising in relation
\end{abstract}

\footnotetext{
Abbreviations: SCB, sugarcane bagasse; CSM, cottonseed meal; WB, wheat bran; OT, oat; SBM, soybean meal; SSF, solid-state fermentation; PDA, potato dextrose agar; FPase, cellulase activity on filter paper; FPU, filter paper unit; CCD, face centered central composite design; HPLC, high pressure liquid chromatography

* Corresponding author.

E-mail addresses: nataliapaganini@hotmail.com (N.P. Marques), josianipereira@gmail.com (J. de Cassia Pereira), eleni@ibilce.unesp.br (E. Gomes), dasilva@ibilce.unesp.br (R. da Silva), araujoar@iq.unesp.br (A.R. Araújo), henfer@rc.unesp.br (H. Ferreira), andrer@rc.unesp.br (A. Rodrigues), kelly.medina@iq.unesp.br (K.J. Dussán), danibocchini@iq.unesp.br (D.A. Bocchini).
} 
to the production of cellulases and xylanases and their enzymatic extracts have potential for application in pretreated sugarcane bagasse saccharification processes.

\section{Introduction}

Endophytic fungi are a very diverse group of microorganisms present in most (if not all) plants in the natural ecosystem without causing external symptoms (Kogel et al., 2006) and have been intensively studied due to their symbiotic relationship with plants and also due to their biotechnological potential as pest control agents and as sources of secondary metabolites, including bioactive substances (Chapla et al., 2014). More recently, they have been reported as producers of plant material degrading enzymes including hydrolases, such as cellulases, xylanases, amylases and pectinases, and oxidative ligninolytic enzymes (Amirita et al., 2012). By the production of these enzymes, they invade and colonize plant tissues and also obtain nutrients. However, most genera of endophytic fungi have been little explored as enzymes sources for biotechnological applications (Corrêa et al., 2014).

Cellulases especially have received attention in recent years, since they are used to saccharify cellulose of lignocellulosic materials releasing glucose that can be converted into cellulosic ethanol by fermenting microorganisms. Cellulosic ethanol is reported as the best alternative biofuel to be used as a substitute for fossil fuels, which besides not being renewable cause environmental impacts from its combustion (Raj and Krishnan, 2018; Nguyen et al., 2017; Harris et al., 2014; Pereira et al., 2016). Xylanases hydrolyze xylan, the main hemicellulosic polysaccharide, which associated to other hemicelluloses components binds to the surface of cellulose microfibrils by hydrogen bonding and hinders cellulase action during saccharification (Farinas et al., 2008). Therefore, the presence of xylanases in the enzymatic cocktail is very important to disrupt xylan and to facilitate the access of cellulases to their substrate, when the objective is to obtain glucose from this cellulose, in the context of sugarcane bagasse saccharification for second generation ethanol production (Kalim et al., 2015). Both cellulases and xylanases can be used in several other industrial processes, highlighting the textile, pulping, and animal nutrition sectors (Goswami and Rawat, 2015; Kuhad et al., 2011).

Enzymatic hydrolysis of cellulose, the main polysaccharide of lignocellulosic materials, to glucose involves the synergistic action of three enzymes: endoglucanases (EC 3.2.1.4) that hydrolyze glycosidic bonds randomly in the amorphous regions of cellulose, generating oligosaccharides with reducing and non-reducing ends for action of exoglucanases or cellobiohydrolases (EC 3.2.1.91), which cleave oligosaccharides to cellobiose, to be hydrolyzed by $\beta$-glucosidases (EC 3.2.1.21) to glucose (Juturu and $\mathrm{Wu}, 2014$ ).

The hydrolysis of xylan, the second most abundant natural polysaccharide of lignocellulosic materials, is accomplished by the synergistic action of endo-xylanases (EC 3.2.1.8) which hydrolyze internal glycosidic bonds randomly on the main chain and $\beta$-xylosidases (EC 3.2.1.37) responsible for the hydrolysis of xylobiose and small xylooligosaccharides from the non-reducing end, releasing xylose (Moreira and Filho, 2016). In recent years, there has been increased the interest in ethanol production from xylose fermentation by some microorganisms (Duangwang et al., 2016). Efficiently mixed fermentation of both hexoses and pentoses may be a viable alternative for ethanol production (Novy et al., 2015).

Considering the potential for biotechnological applications of cellulases and xylanases, the prospect of new microbial sources is important, especially regarding filamentous fungi that are excellent protein secretors. In this sense, endophytic fungi are a promising group considering that most genera have been little explored as hydrolases producers and they most likely produce enzymes with interesting characteristics in terms of access and attack to the polysaccharides of plant cell walls, since they have to invade and colonize plant tissues (Corrêa et al., 2014).

Most of the studies regarding the production of plant degrading enzymes by endophytic fungi involve cultivation on solid media and qualitative evaluation of substrates hydrolysis (Sunitha et al., 2013) (Katoch et al., 2014). Quantitative analysis by submerged fermentation is also cited (Katoch et al., 2014). However, studies using solid-state fermentation (SSF) for this purpose are scarce and involve only some of the most commonly studied endophytic genera such as Acremonium, Alternaria, Aspergillus, Chaetomium and Penicillium (Almeida et al., 2011; Onofre et al., 2013). SSF is advantageous when compared to submerged fermentation in some aspects, including higher yields in a shorter time and the use of widely available and inexpensive lignocellulosic residues as substrates (Ghoshal et al., 2012).

In this context, the aim of the present study was to explore the production of cellulases and xylanases by 14 strains of endophytic fungi, belonging to 13 genera, by SSF using different mixtures of lignocellulosic materials as substrates. Botryosphaeria sp. AM01 and Saccharicola sp. EJC04 were selected and the influence of cultivation time, inoculum concentration and substrate initial moisture content was evaluated, since they are important parameters for enzymes production (Bansal et al., 2012; Yoon et al., 2014). Cellulases and xylanases from the selected fungi were characterized and the crude enzymatic extracts were used to saccharify sugarcane bagasse submitted to alkaline hydrothermal pretreatment.

\section{Material and methods}

\subsection{Microorganisms, maintenance and inoculum}

The endophytic fungi used in this study belong to the working collection of the Center for Bioassays, Biosynthesis and Ecophysiology of Natural Products (NUBBE), IQ/UNESP, Araraquara, São Paulo State, Brazil. Stock cultures were maintained on PDA, in cryovials, at $-80^{\circ} \mathrm{C}$, under a $20 \%$ aqueous glycerol solution. Fourteen strains of the different genera were randomly chosen (Table 1 ), cultured on potato dextrose agar (PDA) at $28^{\circ} \mathrm{C}$, until complete mycelial growth (about 7 days) and

Table 1

Enzymes activities obtained by endophytic fungi cultivation, by SSF, at 7 days, under $28^{\circ} \mathrm{C}$, using a mixture $(5 \mathrm{~g} ; 1: 1 \mathrm{w} / \mathrm{w})$ of sugarcane bagasse and wheat bran as substrates, with the initial moisture of $70 \%$ and 5 mycelial discs as inoculum. EG: endoglucanase; $\beta \mathrm{G}$ : $\beta$-glucosidase; XYL: xylanase; $\beta \mathrm{X}$ : $\beta$-xylosidase.

\begin{tabular}{|c|c|c|c|c|c|}
\hline \multirow[t]{2}{*}{ Fungi } & \multicolumn{5}{|c|}{ Enzymes activities $\left(\mathrm{Ug}^{-1}\right)$} \\
\hline & EG & $\beta G$ & Fpase & XYL & $\beta X$ \\
\hline Acremonium sp. CSF 17 & 11.66 & 4.22 & 0.07 & 144.87 & 0.20 \\
\hline Myrothecium gramineum CSF 23 & 17.90 & 1.03 & 0.08 & 145.48 & 0.02 \\
\hline Colletotrichum crassipes CSY 02 & 5.32 & 0.43 & 0.08 & 8.33 & ND \\
\hline Coniothyrium minitans CV 03 & 13.02 & 8.27 & 0.06 & 407.24 & 0.08 \\
\hline Ustilaginoidea sp. CV 04 & 18.70 & 29.74 & 0.08 & 367.43 & 1.20 \\
\hline Trichoderma viridae PAJ 01 & 64.56 & 2.97 & 0.26 & 351.74 & 0.53 \\
\hline Cladosporium cladosporioides PAJ 03 & 88.50 & 11.88 & 0.20 & 569.48 & 1.52 \\
\hline Phomopsis stipata SC 04 & 83.43 & 24.76 & 0.16 & 694.33 & 0.24 \\
\hline Paecilomyces sp. SF 021 & 1.43 & 33.19 & 0.02 & 7.06 & 2.15 \\
\hline Chaetomium sp. TCF 01 & 12.13 & 3.81 & 0.09 & 39.75 & 0.21 \\
\hline Coniella petrakii PM 02 & 14.66 & 16.58 & 0.10 & 21.54 & 13.07 \\
\hline Botryosphaeria sp. AM01 & 42.78 & 13.76 & 0.25 & 424.73 & 4.87 \\
\hline Saccharicola sp. EJC04 & 39.22 & 51.56 & 0.155 & 103.80 & 4.24 \\
\hline Ustilaginoidea sp. XYA 04 & 14.61 & 21.72 & 0.06 & 299.28 & 0.76 \\
\hline
\end{tabular}

*ND: not detected. 
then mycelial plugs of $8.0 \mathrm{~mm}$ diameter were used as inoculum, as described below.

\subsection{Lignocellulosic substrates for solid-state fermentation (SSF)}

Sugarcane bagasse (SCB) was donated by the Usina Virgolino de Oliveira S/A, located in José Bonifácio, São Paulo, Brazil. Wheat bran (WB), cottonseed meal (CSM), and soybean meal (SBM) were donated by Nutreco Brasil, located in Mirassol, São Paulo, Brazil, and oat (OT) was purchased from the local market. All the lignocellulosic substrates, except OT, were washed and dried in advance under air circulation, at $40^{\circ} \mathrm{C}$. Sugarcane bagasse was triturated with a crusher and passed through a sieve to select particles with a $0.59 \mathrm{~mm}$ mesh.

\subsection{Endophytic fungi screening for enzymes production by SSF}

Fungi were initially cultured by SSF in a mixture $(5.0 \mathrm{~g} ; 1: 1 \mathrm{w} / \mathrm{w})$ of SCB and WB as sole carbon sources, in autoclavable polypropylene bags $(16 \times 22 \mathrm{~cm})$ sealed with cotton stoppers (Merheb-Dini et al., 2010). Each fermentation bag was inoculated with 5 mycelial plugs from a preculture on a PDA plate and a moisture content of $70 \%(\mathrm{w} / \mathrm{v})$ was standardized using a nutrient solution composed of $\left(\mathrm{g} . \mathrm{L}^{-1}\right)(\mathrm{NH})_{4} \mathrm{SO}_{4}$ (3.5), $\mathrm{KH}_{2} \mathrm{PO}_{4}$ (3.0), $\mathrm{MgSO}_{4} .7 \mathrm{H}_{2} \mathrm{O}(0.5), \mathrm{CaCl}_{2}$ (0.5) and Tween 80 (10.0), with $\mathrm{pH}$ adjusted to 5.0 (NaOH $1 \mathrm{M}$ ) (MANDELS; STERNBERG, 1976). Fungi were cultivated at $28^{\circ} \mathrm{C}$ for 7 days, time considered suitable for fungal growth (visual evaluation) and within the range frequently cited in literature (Yoon et al., 2014, Mangalanayaki and Madhavan, 2015). Then, $50.0 \mathrm{~mL}$ of distilled water were added to each fermentation bag for enzymes extraction, the material was manually homogenized, transferred to a $250 \mathrm{~mL}$ Erlenmeyer flask and maintained at $150 \mathrm{rpm}$, for $1 \mathrm{~h}$, at room temperature. The mixture was filtered through nylon cloth, centrifuged at $10.000 \times g$, at $4{ }^{\circ} \mathrm{C}$, for $15 \mathrm{~min}$, and the supernatant was used as the crude enzymatic extract (Moretti et al., 2012; Pereira et al., 2015). All cultivations were performed in duplicate. At this stage, eight fungi were preselected based on their cellulases production.

\subsection{Influence of different substrates on enzymes production by SSF}

Preselected fungi were cultivated, by SSF, using other mixtures (5.0 $\mathrm{g} ; 1: 1 \mathrm{w} / \mathrm{w})$ of lignocellulosic materials as substrates (CSM:WB; SCB:OT; SCB:CSM; SCB:SBM) and the enzymatic activities were quantified. Solid state fermentation was performed as described above, all cultivations were performed in duplicate and, at this stage, two fungi were selected based on cellulases production, to continue the study.

\subsection{Influence of cultivation time, inoculum concentration and substrate moisture content on enzymes production by SSF}

The two selected fungi were cultivated by SSF in the appropriate substrate, for 14 days, in order to determine the peak of cellulases and xylanases production. Every $48 \mathrm{~h}$, a fermentation bag was taken for enzymes extraction and quantitative evaluation of enzymatic activities. Then, the influence of inoculum amount $(3,6,9$ or 12 mycelial plugs of $8.0 \mathrm{~mm}$ diameter) and substrate initial moisture content $(60,65,70,75$ or $80 \%$ ) on the enzymes production was evaluated. The levels of inoculum amount and substrate initial moisture used were defined within the range commonly reported in literature (Acharya et al., 2008; Zilly et al., 2012; Delabona et al., 2013).

\subsection{Enzymatic assays}

Cellulase activity on filter paper (FPase) was determined as described by Ghose (1987) and expressed as filter paper unit (FPU), $\beta$ glucosidase activity was assayed according to Leite et al. (2008), endoglucanase, exoglucanase (avicelase), $\beta$-xylosidase and xylanase activities were determined as described by Cassia Pereira et al. (2015). Enzymes activities expressed as $\mathrm{Ug}^{-1}$ refer to unit per gram of dry substrate.

\subsection{Enzymes physicochemical characteristics}

Optimal $\mathrm{pH}$ for enzymes activities was determined according to Cassia Pereira et al. (2015) by incubating the reaction mixtures with different $\mathrm{pH}$ values at $45^{\circ} \mathrm{C}$, for $10 \mathrm{~min}$. The temperature effect on enzymes activities was evaluated by incubating the reaction mixtures, at optimum $\mathrm{pH}$, at $30-80^{\circ} \mathrm{C}$, for $10 \mathrm{~min}$. For optimum $\mathrm{pH}$ and temperature, the highest value obtained was considered to be $100 \%$. The effects of $\mathrm{pH}$ and temperature on enzymes stability were evaluated according to Cassia Pereira et al. (2015). For pH and thermal stability, the enzymatic activity before treatments was defined as $100 \%$.

\subsection{Glucose and ethanol effects on $\beta$-glucosidases activities}

$\beta$-glucosidases activities were quantified according to Leite et al. (2008), at $45^{\circ} \mathrm{C}$, with the addition of glucose $\left(2.0-12.0 \mathrm{mmol} \mathrm{L}^{-1}\right)$ or ethanol (5-25\%) to the reaction mixture.

\subsection{Sugarcane bagasse hydrothermal pretreatment}

Sugarcane bagasse was autoclaved $(5 \% \mathrm{w} / \mathrm{v}$ in $0.5 \mathrm{M} \mathrm{NaOH}$ solution) in a $250 \mathrm{~mL}$ Erlenmeyer flask, sealed with aluminum foil, at $120^{\circ} \mathrm{C}$ and $1 \mathrm{~atm}$, for $1 \mathrm{~h}$. After this, the flask was cooled and then kept at room temperature for stabilization. The material was washed thoroughly with tap water and distilled water, filtered manually with a cotton fabric and the solid phase was stored at $4{ }^{\circ} \mathrm{C}$. Pretreated bagasse was characterized for total lignin, cellulose and xylan using the NREL (National Renewable Energy Laboratory - USA) procedure (Sluiter et al., 2008). The composition of in natura sugarcane bagasse was $38.6 \pm 2.1,16.33 \pm 0.8$ and $27.47 \pm 1.6 \%$ of cellulose, xylan and lignin, respectively. After pretreatment, the composition was $63.32 \pm 1.3,14.00 \pm 0.9$ and $17.24 \pm 1.9 \%$, respectively.

\subsection{Enzymatic saccharification of pretreated sugarcane bagasse}

Saccharification of pretreated SCB was performed using a blend $(1: 1 \mathrm{v} / \mathrm{v})$ of the enzymatic extracts from the selected fungi Botryosphaeria sp. AM01 and Saccharicola sp. EJC04. A face centered central composite design (CCD) $\left(2^{4}\right.$, including 8 axial points and 4 repetitions of central points, totaling 28 trials) was used to evaluate the influence of: biomass loading (3, 5 and $7 \%$ of dry basis), enzyme loading (100, 150 and $200 \mathrm{U} \mathrm{g}^{-1}$ of endoglucanase), temperature (50, 55 and $60^{\circ} \mathrm{C}$ ) and incubation time (16, 20 and $24 \mathrm{~h}$ ) and the response evaluated was glucose concentration in the hydrolysates. The experiments were carried out in $125 \mathrm{~mL}$ Erlenmeyer flasks, and a final volume of $20 \mathrm{~mL}$ was reached with a citrate buffer $\left(0.1 \mathrm{~mol} \mathrm{~L}^{-1}, \mathrm{pH} 5.0\right)$. The flasks were sealed with latex caps, incubated in an orbital shaker, at $200 \mathrm{rpm}$. At defined time intervals, individual flasks were taken, as duplicates, cooled in an ice bath, their contents were filtered through a nylon cloth and glucose in the liquid phase was quantified by high pressure liquid chromatography (HPLC) according to Cassia Pereira et al. (2015). Xylose was also quantified as additional data, by the same procedure.

Variance analysis (ANOVA) was performed to estimate the effect of biomass loading, enzyme loading, temperature and incubation time, and their interactions for glucose concentration. Hence, $\mathrm{p}<0.05$ was considered statistically significant. Regression and graphical analysis were accomplished using the Statistica 10 software (StatSoft Inc., Tulsa, Oklahoma, USA). 


\section{Results and discussion}

\subsection{Endophytic fungi screening for enzymes production by SSF}

As an initial screening, fungi were cultivated by SSF using sugarcane bagasse and wheat bran as substrates, good inducers for several plant material degrading enzymes (Moretti et al., 2014). Enzymes activities obtained are shown in Table 1.

Endoglucanases and $\beta$-glucosidases activities obtained in the present study are similar to or even higher than some reported in literature regarding SSF using endophytic fungi (Almeida et al., 2011; Damaso et al., 2012). Cellulases activities on filter paper obtained were lower than those frequently reported in literature. According to Dashtban et al. (2010), this activity varies widely among microbial cellulases. On the other hand, good activities of endoglucanase and $\beta$-glucosidase were obtained. Exoglucanase activity was not detected in the enzymatic extracts.

Expressive xylanase activities were observed in the first screening of the present study: 694.33 ; $569.48 ; 424.62$ and $407.23 \mathrm{U} \mathrm{g}^{-1}$ for isolates SC 04, PAJ 03, AM01 and CV 03, respectively.

Eight fungi were preselected from this first screening, based on cellulases production: $T$. viridae PAJ 01, P. stipata SC 04, Paecilomyces sp. SF 021, C. cladosporioides PAJ 03, Ustilaginoidea sp. CV 04, Ustilaginoidea sp. XYA 04, Botryosphaeria sp. AM 01 and Saccharicola sp. EJC 04. Due to the problems related to FPase activity cited above, the selection was based on endoglucanase and/or $\beta$-glucosidase activities. Xylanase activities were also determined throughout the study.

\subsection{Influence of other lignocellulosic substrates on enzymes production}

The eight preselected fungi were cultivated by SSF on other mixtures of lignocellulosic substrates in order to evaluate the influence on cellulases production (Table 2). The initial culture conditions were maintained. Activities that increased, when compared to the first screening, are highlighted in bold (Table 2).

The most pronounced increases of endoglucanases and $\beta$-glucosidases production were observed for Botryosphaeria sp. AM 01, when grown on CSM:WB. In general, SCB:OT led to lower cellulases production, except for Paecilomyces sp. 021, Ustilaginoidea sp. XYA 04 (endoglucanase) and for Ustilaginoidea sp. CV 04 (both enzymes) (Table 2). Xylanases production was slightly improved for Botryosphaeria sp. AM01 and Paecilomyces sp. SF 021. $\beta$-xylosidases production was improved for all fungi, except for Saccharicola sp. EJC 04 (Table 2).

Based on these results and on cellulases activities obtained, Botryosphaeria sp. AM01, Paecilomyces sp. SF 021 and Saccharicola sp. EJC04 were chosen and then were cultivated by SSF on two new mixtures of substrates: SCB:CSM and SCB:SBM. The initial culture conditions (as described in Section 2.3) were maintained and enzymes
Table 3

Enzymes activities obtained by the cultivation of the 3 preselected strains, by $\mathrm{SSF}$, under $28^{\circ} \mathrm{C}$, at 7 days, using the mixture $(5 \mathrm{~g}, 1: 1 \mathrm{w} / \mathrm{w})$ of sugarcane bagasse and cottonseed meal (SCB:CSM) or sugarcane bagasse and soybean meal (SCB:SBM) as substrates. Values in parenthesis represent how many times the enzyme activity was increased when compared to the highest previously obtained.

\begin{tabular}{lllll}
\hline & & & \multicolumn{2}{c}{$\begin{array}{c}\text { Strains and enzymatic activities } \\
\left(\mathrm{U} \mathrm{g}^{-1}\right)\end{array}$} \\
\cline { 4 - 5 } Enzymes & Substrates & $\begin{array}{l}\text { Botryosphaeria } \\
\text { sp. AM 01 }\end{array}$ & $\begin{array}{l}\text { Paecilomyces } \\
\text { sp. SF 021 }\end{array}$ & $\begin{array}{l}\text { Saccharicola } \\
\text { sp. EJC04 }\end{array}$ \\
\hline \multirow{2}{*}{ Endoglucanase } & SCB + CSM & 144.07 & $\mathbf{4 . 8}(2.07)$ & 27.16 \\
& SCB + SBM & 130.45 & $\mathbf{5 . 4 2}(2.34)$ & 21.50 \\
B-glucosidase & SCB + CSM & 20.06 & 5.42 & 51.47 \\
Xylanase & SCB + SBM & $\mathbf{1 5 7 . 5 7}(3.43)$ & 6.36 & 33.91 \\
& SCB + CSM & 85.25 & 1.55 & 21.66 \\
B-xylosidase & SCB + SBM & 48.45 & 0.91 & 9.96 \\
& SCB + CSM & 2.83 & 1.55 & 2.74 \\
& SCB + SBM & 2.23 & 1.39 & 1.09 \\
\hline
\end{tabular}

activities are shown in Table 3. Enzymatic activities higher than those obtained by the cultivation on mixtures of SCB:WB (Table 1) are highlighted in bold in Table 3.

The use of SCB:SBM improved endoglucanase and $\beta$-glucosidase production by Paecilomyces sp. SF 021 and Botryosphaeria AM 01, respectively. However, cultivations on this mixture of substrates did not provide expressive xylanases production (Table 3). Lower production of endoglucanase by the endophytic fungus Rhizopus oryzae PR7, cultivated by SSF on sugarcane bagasse and/or cotton seed (1.8 and $0.1 \mathrm{U} \mathrm{mL}^{-1}$, respectively), was reported by Karmakar and Ray (2010). A significant increase in cellulases activities was reported by RodríguezZúniga et al. (2011) with the increase of wheat bran and soybean meal proportion in the mixture of substrates, when compared to the cultivation using only sugarcane bagasse.

Several studies regarding cellulolytic enzymes production using different microorganisms, substrates and culture conditions are found in literature, with a wide variation in the activities obtained (Hansen et al., 2015; de Oliveira et al., 2016; Yadav et al., 2016).

Since Botryosphaeria sp. AM01 and Saccharicola sp. EJC04 were the best cellulases producers in all cultivations, they were ultimately selected to continue the study.

\subsection{Cellulases production by the selected fungi Botryosphaeria sp. AM01} and Saccharicola sp. EJCO4 under different culture conditions

\subsubsection{Cultivation time influence}

Botryosphaeria sp. AM01 and Saccharicola sp. EJC04 were cultivated by SSF on CSM:WB, most suitable substrates for cellulases production, for up to 14 days, in order to determine the peaks of enzymes activities.

Table 2

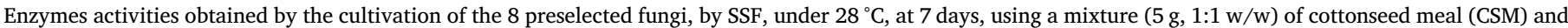

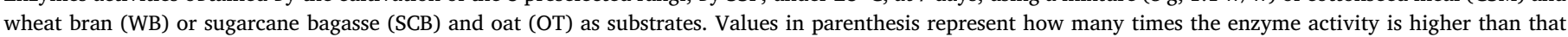
obtained in the screening.

\begin{tabular}{|c|c|c|c|c|c|c|c|c|}
\hline \multirow[b]{2}{*}{ Enzymes } & \multirow[b]{2}{*}{ Substrates } & \multicolumn{7}{|c|}{ Strains and enzymatic activities $\left(\mathrm{Ug}^{-1}\right)$} \\
\hline & & $\begin{array}{l}\text { Botryosphaeria sp. } \\
\text { AM } 01\end{array}$ & $\begin{array}{l}\text { Paecilomyces sp. } \\
\text { SF } 021\end{array}$ & $\begin{array}{l}\text { Saccharicola sp. } \\
\text { EJC04 }\end{array}$ & $\begin{array}{l}\text { Phomopsis } \\
\text { stipata SCO4 }\end{array}$ & $\begin{array}{l}\text { Ustilaginoidea sp. } \\
\text { CV } 04\end{array}$ & $\begin{array}{l}\text { Cladosporium } \\
\text { cladosporioides PAJ } 03\end{array}$ & $\begin{array}{l}\text { Ustilaginoidea sp. } \\
\text { XYA } 04\end{array}$ \\
\hline \multirow[t]{2}{*}{ Endoglucanase } & $\mathrm{CSM}+\mathrm{WB}$ & $184.74(4.31)$ & $1.60(1.10)$ & 22.27 & 15.25 & 5.11 & 33.59 & 11.46 \\
\hline & $\mathrm{SCB}+\mathrm{OT}$ & 9.23 & $2.31(1.61)$ & 5.53 & 4.11 & $19.70(1.05)$ & 5.96 & $24.25(1.66)$ \\
\hline \multirow[t]{2}{*}{$\beta$-glucosidase } & $\mathrm{CSM}+\mathrm{WB}$ & $45.95(3.34)$ & $91.29(2.75)$ & $92.04(1.80)$ & 23.10 & 25.95 & $14.57(1.20)$ & $27.41(1.26)$ \\
\hline & $\mathrm{SCB}+\mathrm{OT}$ & 4.69 & 27.58 & $55.92(1.08)$ & 7.58 & $35.45(1.20)$ & 3.70 & 19.74 \\
\hline \multirow[t]{2}{*}{ Xylanase } & $\mathrm{CSM}+\mathrm{WB}$ & $442.58(1.04)$ & $8.93(1.26)$ & 19.25 & 21.42 & 15.87 & 26.97 & 11.83 \\
\hline & $\mathrm{SCB}+\mathrm{OT}$ & 51.62 & 9.66 (1.37) & 8.57 & 83.59 & 153.92 & 48.31 & 187.09 \\
\hline \multirow[t]{2}{*}{$\beta$-xylosidase } & $\mathrm{CSM}+\mathrm{WB}$ & $10.42(2.13)$ & $7.51(3.5)$ & 2.64 & 2.25 & $1.42(1.18)$ & $2.00(1.31)$ & $1.95(2.56)$ \\
\hline & $\mathrm{SCB}+\mathrm{OT}$ & 1.11 & $3.85(1.8)$ & 0.59 & 0.25 & $1.74(1.45)$ & 0.93 & $1.12(1.47)$ \\
\hline
\end{tabular}


Maximum endoglucanase activities were obtained at 192 and $96 \mathrm{~h}$, for Botryosphaeria sp. AM $01\left(251.12 \mathrm{U} \mathrm{g}^{-1}\right)$ and Saccharicola sp. EJC 04 $\left(28.84 \mathrm{U} \mathrm{g}^{-1}\right.$ ), respectively (Fig. $1 \mathrm{a}$ and b). These activities are higher than those obtained in the previous cultivation in the same substrates (Table 2), which was maintained for $168 \mathrm{~h}$. Besides this peak of endoglucanase production by Saccharicola EJC 04 was observed at a very short time when compared to the previous cultivation in the same substrates. Regarding $\beta$-glucosidase, Saccharicola sp. EJC 04 stood out with an activity of $107.28 \mathrm{U} \mathrm{g}^{-1}$, at $192 \mathrm{~h}$ (Fig. 1a and b). The highest FPase activities were achieved at 192 and $144 \mathrm{~h}$, by Botryosphaeria sp. AM 01 (2.78 $\left.\mathrm{FPU} \mathrm{g}^{-1}\right)$ and Saccharicola sp. EJC $04\left(0.42 \mathrm{FPU} \mathrm{g}^{-1}\right)$, respectively (Fig. $1 \mathrm{a}$ and $\mathrm{b}$ ).

Maximum xylanases activities were observed at $192 \mathrm{~h}$ (187.17 $\left.\mathrm{U} \mathrm{g}^{-1}\right)$ for Botryosphaeria sp. AM 01 and at $96 \mathrm{~h}\left(25.47 \mathrm{U} \mathrm{g}^{-1}\right)$ for Saccharicola sp. EJC 04. The highest $\beta$-xylosidase activities were

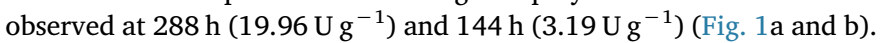
Highest enzymes productions were obtained at $192 \mathrm{~h}$ or near what usually occurs with mesophilic fungi, after its complete development, including mesophilic endophytic fungi, when cultivated by SSF (Delabona, 2011; Kang et al., 2004; Muthezhilan et al., 2007; Zhang and Sang, 2012), so this period was defined for further experiments.

\subsubsection{Influence of the inoculum size}

To evaluate the effect of the inoculum amount on cellulases production, Botryosphaeria sp. AM01 and Saccharicola sp. EJC04 were cultivated by SSF, on cottonseed meal and wheat bran, using 3, 6, 9 or 12 mycelial plugs as inoculum. Enzymes activities obtained are shown in.

For Botryosphaeria sp. AM01, the most pronounced effect was observed for endoglucanase when the amount of inoculum increased from 3 to 6 mycelial plugs (Fig. 2a). Enzyme activity obtained from Saccharicola sp. EJC04 was very close in all inoculum amounts evaluated (Fig. 2b).

Most literature data concerning the influence of inoculum concentration on fungal cellulases production by SSF cites the use of spores (Zhang and Sang, 2012; Xu et al., 2018). Therefore, it is difficult to compare these data to the results of the present study. Acharya et al. (2008) cultivated Aspergillus niger by submerged fermentation, using sawdust as a substrate, and noted that a high amount of inoculum (15 or 20 mycelial plugs) decreased endoglucanase production. Zilly et al. (2012), in order to obtain hydrolytic enzymes from Pleurotus pulmonarius by SSF using wheat bran as substrate and 3 mycelial plugs of $10 \mathrm{~mm}$ diameter as inoculum, obtained a $\beta$-glucosidase production of $22 \mathrm{Ug}^{-1}$, lower than that obtained from some fungi of the present study, using the same amount of inoculum.

Since 6 mycelial plugs provided satisfactory cellulases activities by both fungi, this amount of inoculum was used in further experiments.

\subsubsection{Substrate initial moisture content influence}

For Botryosphaeria sp. AM01, endoglucanase activity decreased at a substrate moisture content higher than $65 \%$, and other enzymes activities remained nearly at the same level (Fig. 3a). In general, the initial substrates moisture content evaluated did not markedly influence enzymes production by Saccharicola sp. EJC 04 (Fig. 3b). These results are in accordance with certain literature data where higher enzymes production by SSF were obtained from a substrate moisture content around 70\% (Liang et al., 2012; Maurya et al., 2012). Therefore, 65\% was fixed as the moisture content to be used in the next experiments.

\subsection{Enzymes physicochemical characteristics}

\subsubsection{Effect of $\mathrm{pH}$ and temperature on enzymes activity and stability}

Botryosphaeria sp. AM01 and Saccharicola sp. EJC04 were cultivated by SSF, at $28^{\circ} \mathrm{C}$, on CSM:WB as substrates $(1: 1 \mathrm{w} / \mathrm{w})$, for $192 \mathrm{~h}$, using 6 mycelial plugs as inoculum and an initial substrate moisture content of $65 \%$ and the enzymatic extracts were used to evaluate physicochemical characteristics of cellulases and xylanases (Table 4). An interesting fact to consider is that, after determining optimum $\mathrm{pH}$ and temperature conditions, there was a significant increase of all enzymes activities, especially regarding $\beta$-glucosidase from EJC $04\left(488 \mathrm{Ug}^{-1}, 4\right.$ fold higher than that determined before characterization). Similar results were reported by Almeida et al. (2011) and Wipusaree et al. (2011).

Regarding stability, endoglucanase produced by Botryosphaeria sp. AM01 was more resistant to $\mathrm{pH}$ variation, maintaining $81-94 \%$ of its activity after $24 \mathrm{~h}$ of incubation at $\mathrm{pH} 3.5-8.5$. Endoglucanase from Saccharicola sp. EJC 04 lost approximately $50 \%$ of its activity after $24 \mathrm{~h}$ of incubation at $\mathrm{pH}$ 3.5-9.0. $\beta$-glucosidases from both strains showed similar performance after incubation at different $\mathrm{pH}$ values, retaining approximately $50-85 \%$ of activity at $\mathrm{pH} 3.5-10.5$. Xylanases from Botryosphaeria sp. AM01 and Saccharicola sp. EJC 04 maintained around 90 and $50 \%$ of their activities at $\mathrm{pH} 3.5-7.0$. $\beta$-xylosidases from these fungi were stable at a $\mathrm{pH}$ range of 3.5-7.0 (90\% of activity) and a 3.59.0 range (87\% of activity), respectively. Endoglucanase from Botryosphaeria sp. AM01 was very stable after $1 \mathrm{~h}$ of incubation at $30-50{ }^{\circ} \mathrm{C}$ ( $97 \%$ of the original activity). On the other hand, endoglucanase from Saccharicola sp. EJC 04 maintained about $67 \%$ of its activity after incubation at $45^{\circ} \mathrm{C}$. $\beta$-glucosidase from Botryosphaeria sp. AM01 was stable under a broad temperature range $\left(30-60^{\circ} \mathrm{C}\right)$, retaining about $100 \%$ of its activity when incubated at $40^{\circ} \mathrm{C}$. $\beta$-glucosidase from Saccharicola sp. EJC 04 drastically lost its stability when incubated at temperatures above $70{ }^{\circ} \mathrm{C}$. Cellulases from the present study were more stable to $\mathrm{pH}$ and temperature variations when compared to those reported by Song and Wei (2010) and Almeida et al. (2011).

(a)

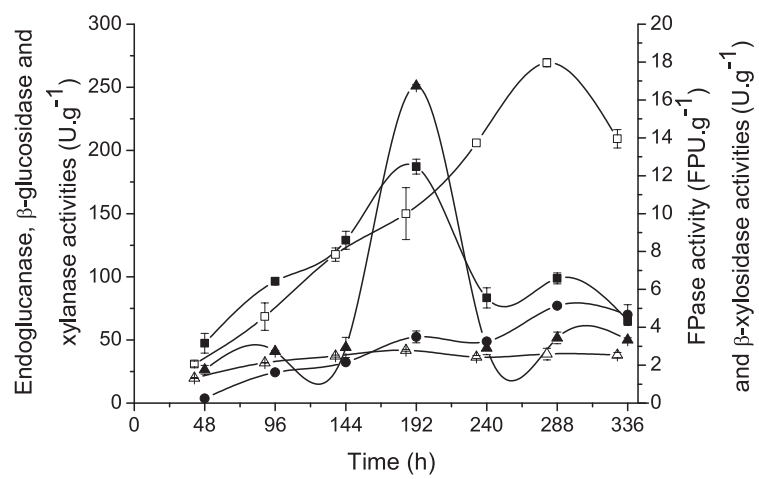

(b)

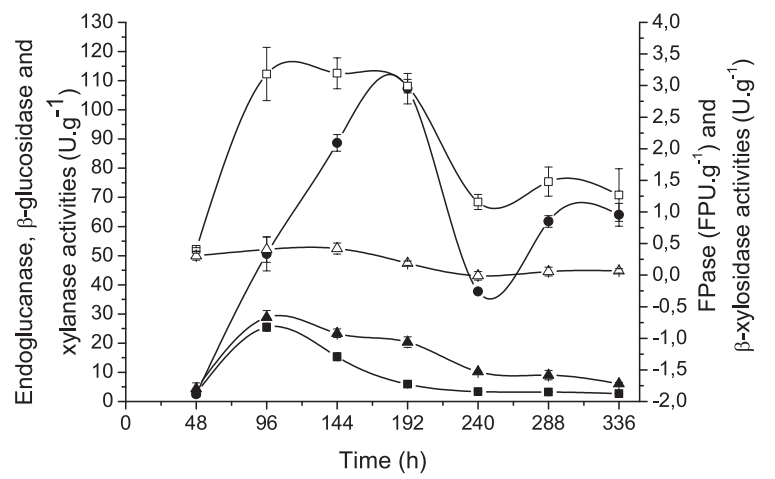

Fig. 1. Time course of cellulases and xylanases production by Botryosphaeria sp. AM01 (a) and Saccharicola sp. EJC04 (b), by SSF, on mixture (5 g, 1:1 w/w) of cottonseed meal and wheat bran, at $28^{\circ} \mathrm{C}$. Endoglucanase (- $\left.\boldsymbol{\Delta}^{-}\right), \beta$-glucosidase (-๑), FPase (- $\triangle$-), Xylanase (- $\square$-) and $\beta$-xylosidase (- $\square$-). 
(a)

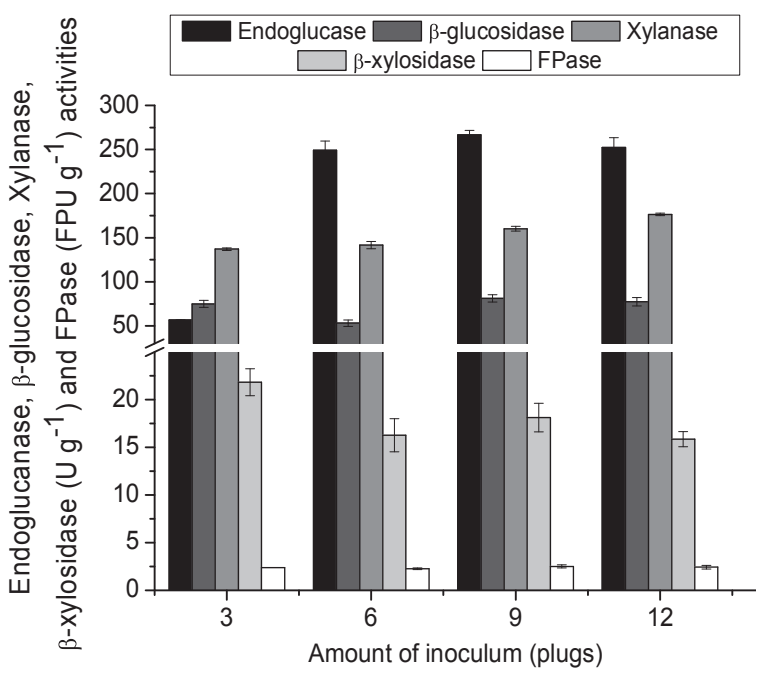

(b)

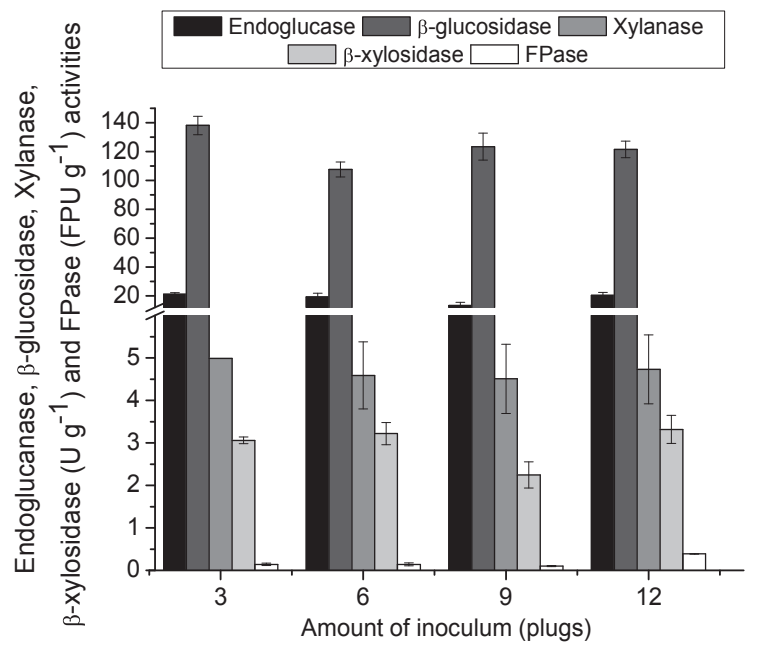

Fig. 2. Influence of inoculum amount on cellulases and xylanases production by Botryosphaeria sp. AM01 (a) and Saccharicola sp. EJC04 (b), by SSF, at $28{ }^{\circ} \mathrm{C}$, for $192 \mathrm{~h}$, using a mixture $(5 \mathrm{~g}, 1: 1 \mathrm{w} / \mathrm{w})$ of cottonseed meal and wheat bran as substrates.

The enzymes from Botryosphaeria sp. AM 01 and Saccharicola sp. EJC 04 showed optimal activity at pH around 5.0-6.0 and high optimum temperatures and were stable at a broad range of $\mathrm{pH}$ and temperature. These enzymes characteristics are very important for some industrial processes (Nigam, 2013).

\subsubsection{Glucose and ethanol effects on $\beta$-glucosidases activities}

In Fig. 4a we can observe that when glucose concentration is increased, $\beta$-glucosidases activities decreased, indicating that enzymes are inhibited by the product. In the enzymatic hydrolysis of lignocellulose biomass to fermentable sugars, an inevitable consequence is the accumulation of hydrolysis products at high concentrations, which may result in cellulases inhibition (Kuusk and Väljamäe, 2017), as observed in this study for $\beta$-glucosidases from the two selected fungi. According to (Guimarães et al., 2006), glucose inhibition is commonly cited in studies regarding microbial $\beta$-glucosidases. Alcohol inhibition is also an important topic in the study of $\beta$-glucosidases (Sun and Cheng, 2002) especially when these enzymes are used for simultaneous saccharification and fermentation processes. The activity of $\beta$-glucosidase from Saccharicola sp. EJC04 was reduced at ethanol concentrations (a)

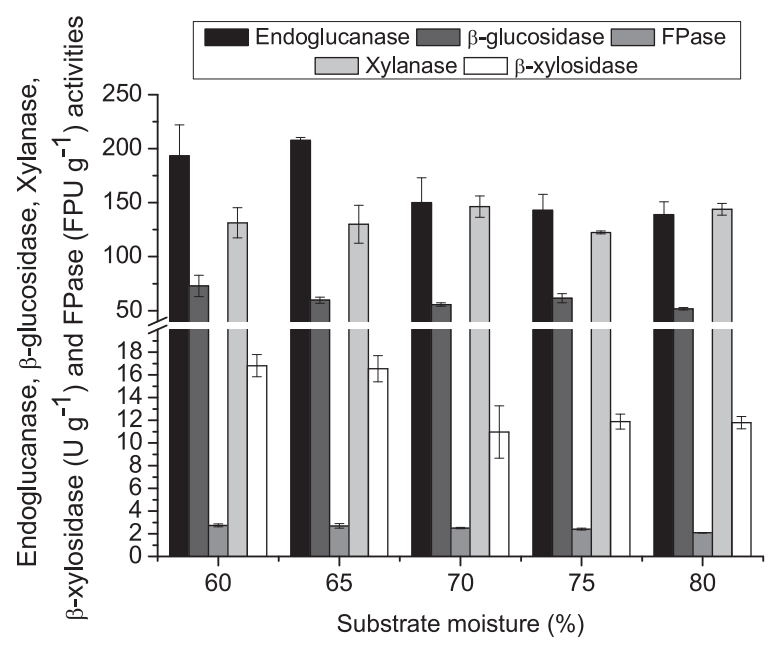

(b)

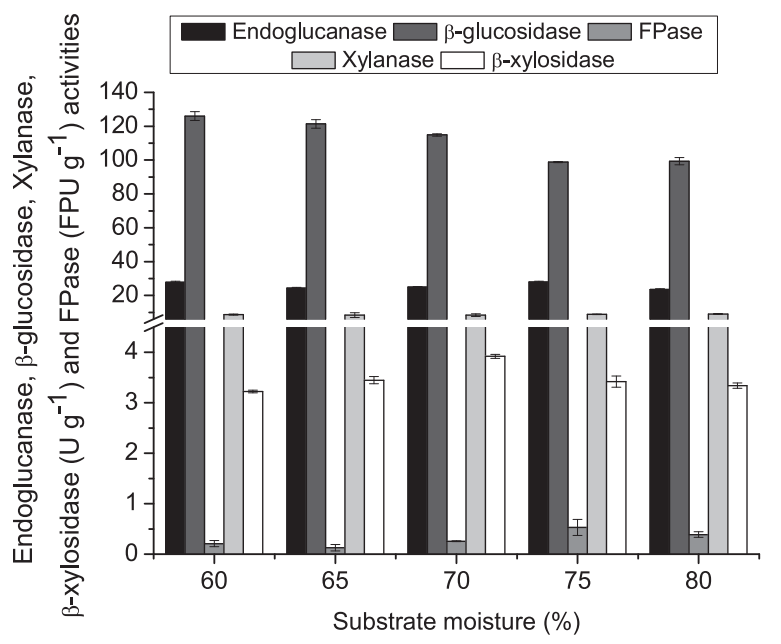

Fig. 3. Influence of substrate initial moisture content on cellulases and xylanases production by Botryosphaeria sp. AM01 (a) and Saccharicola sp. EJC04 (b), by SSF, at $28^{\circ} \mathrm{C}$, for $192 \mathrm{~h}$, using a mixture $(5 \mathrm{~g} ; 1: 1 \mathrm{w} / \mathrm{w})$ of cottonseed meal and wheat bran as substrates and 6 mycelial plugs as inoculum.

above 15\% (Fig. 4b). Ethanol alters medium polarity and this most likely causes conformational changes on enzyme structure or enzyme denaturation (Barbagallo et al., 2004). On the other hand, ethanol increased Botryosphaeria sp. AM01 $\beta$-glucosidase's activity (Fig. 4b) and similar data were reported by Krisch et al. (2012) and Leite et al. (2008). The increase in enzymatic activity observed at low ethanol concentrations could be due to the action of $\beta$-glucosidase as a $\beta$-glycosyltransferase (Villena et al., 2006). In this case, ethanol, in addition to water, acts as an acceptor for an intermediary glycosyl group (Pemberton et al., 1980). The glucosyltransferase activity of $\beta$-glucosidase is a very interesting characteristic for use in simultaneous saccharification and fermentation (Leite et al., 2008).

\subsection{Optimization of sugarcane bagasse saccharification}

For saccharification experiments, the blend $(1: 1 \mathrm{v} / \mathrm{v})$ of enzymatic extracts produced by Botryosphaeria sp. AM01 and Saccharicola sp. EJC04, under the culture conditions selected for each fungus (as described in Section 3.3), was used. Twenty-eight runs were performed based on CCD, as shown in Table 5. Glucose was the response 
Table 4

Cellulases and xylanases physicochemical characteristics.

\begin{tabular}{|c|c|c|c|c|c|c|}
\hline & & & \multicolumn{4}{|l|}{ Enzymes } \\
\hline & & & Endoglucanase & $\beta$-glucosidase & Xylanase & $\beta$-xylosidase \\
\hline \multirow[t]{4}{*}{ Botryosphaeria sp. AM01 } & $\mathrm{pH}$ & Optimum & 6.0 & 5.0 & 5.5 & 4.5 \\
\hline & & Stability & $3.5-9.0$ & $3.5-8.5$ & $3.5-8.5$ & $3.5-7.0$ \\
\hline & Temperature $\left({ }^{\circ} \mathrm{C}\right)$ & Optimum & 60 & 60 & 60 & 70 \\
\hline & & Stability & $30-50$ & $30-60$ & $30-55$ & $30-70$ \\
\hline \multirow[t]{4}{*}{ Saccharicola sp. EJC04 } & $\mathrm{pH}$ & Optimum & 5.0 & 4.5 & 5.0 & 4.5 \\
\hline & & Stability & $3.5-8.5$ & $3.5-6.0$ & $3.5-8.5$ & $3.5-9.0$ \\
\hline & Temperature $\left({ }^{\circ} \mathrm{C}\right)$ & Optimum & 65 & 75 & 60 & 65 \\
\hline & & Stability & $30-50$ & $30-65$ & $30-55$ & $30-60$ \\
\hline
\end{tabular}

(a)

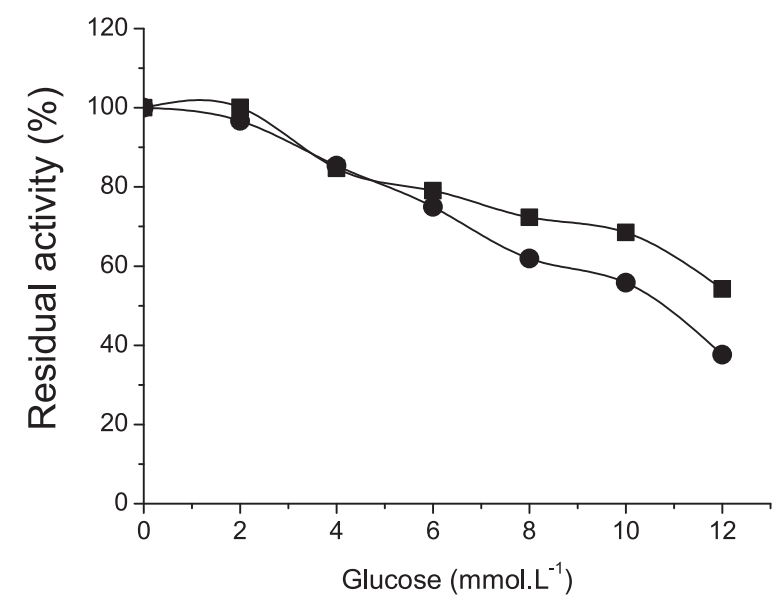

(b)

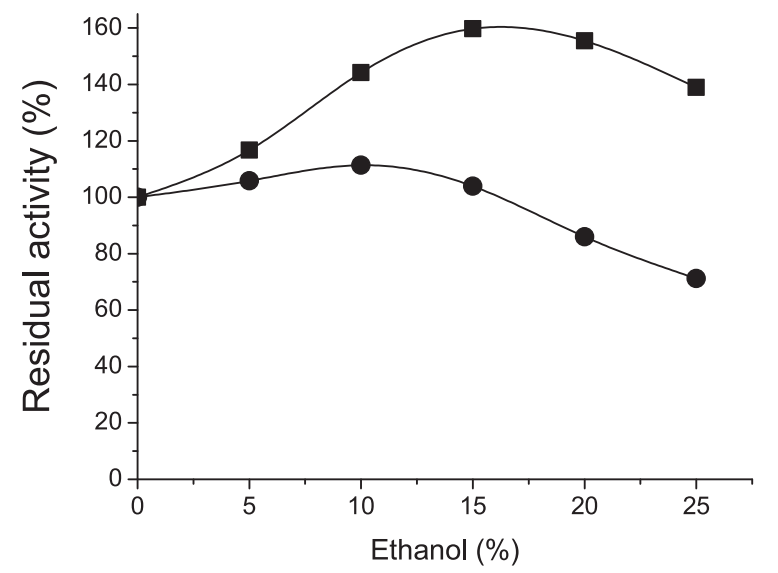

Fig. 4. Effect of glucose (a) and ethanol (b) on $\beta$-glucosidases activities from Botryosphaeria sp. AM01 and (๑) Saccharicola sp. EJC04.

evaluated, taking into account that Saccharomyces cerevisiae, the yeast better adapted to the industrial processes of ethanol production does not ferment pentoses (Radecka et al., 2015).

According to the analysis of variance (ANOVA) (Table 6), the quadratic effects of temperature (0.006) and enzyme load (0.000) were significant at a $95 \%$ confidence level $(\mathrm{p}<0.05)$ for glucose concentration. Interactions between variables were not statistically significant at a $95 \%$ confidence level. The coefficient of determination $\left(R^{2}\right)$ (0.95) indicates that the quadratic model represents the experimental data.

The interaction effects of significant variables on glucose
Table 5

Variables and the glucose concentration according to the face-centered $2^{4}$ factorial design. Coded values of the variables were indicated in parenthesis.

\begin{tabular}{|c|c|c|c|c|c|}
\hline \multirow[b]{2}{*}{ Runs } & \multicolumn{4}{|l|}{ Variables } & \multirow{2}{*}{$\begin{array}{l}\text { Response } \\
\text { Glucose }\left(\mathrm{mg} \mathrm{mL}^{-1}\right)\end{array}$} \\
\hline & $X_{1}$ & $X_{2}$ & $X_{3}$ & $X_{4}$ & \\
\hline 1 & $50(-1)$ & $3(-1)$ & $100(-1)$ & $16(-1)$ & 0.247 \\
\hline 2 & $60(+1)$ & $3(-1)$ & $100(-1)$ & $16(-1)$ & 0.329 \\
\hline 3 & $50(-1)$ & $7(+1)$ & $100(-1)$ & $16(-1)$ & 0.397 \\
\hline 4 & $60(+1)$ & $7(+1)$ & $100(-1)$ & $16(-1)$ & 0.675 \\
\hline 5 & $50(-1)$ & $3(-1)$ & $200(+1)$ & $16(-1)$ & 0.205 \\
\hline 6 & $60(+1)$ & $3(-1)$ & $200(+1)$ & $16(-1)$ & 0.393 \\
\hline 7 & $50(-1)$ & $7(+1)$ & $200(+1)$ & $16(-1)$ & 0.748 \\
\hline 8 & $60(+1)$ & $7(+1)$ & $200(+1)$ & $16(-1)$ & 0.855 \\
\hline 9 & $50(-1)$ & $3(-1)$ & $100(-1)$ & $24(+1)$ & 0.454 \\
\hline 10 & $60(+1)$ & $3(-1)$ & $100(-1)$ & $24(+1)$ & 0.213 \\
\hline 11 & $50(-1)$ & $7(+1)$ & $100(-1)$ & $24(+1)$ & 0.589 \\
\hline 12 & $60(+1)$ & $7(+1)$ & $100(-1)$ & $24(+1)$ & 0.311 \\
\hline 13 & $50(-1)$ & $3(-1)$ & $200(+1)$ & $24(+1)$ & 0.373 \\
\hline 14 & $60(+1)$ & $3(-1)$ & $200(+1)$ & $24(+1)$ & 0.070 \\
\hline 15 & $50(-1)$ & $7(+1)$ & $200(+1)$ & $24(+1)$ & 0.959 \\
\hline 16 & $60(+1)$ & $7(+1)$ & $200(+1)$ & $24(+1)$ & 0.513 \\
\hline 17 & $50(-1)$ & $5(0)$ & $150(0)$ & $20(0)$ & 4.022 \\
\hline 18 & $60(+1)$ & $5(0)$ & $150(0)$ & $20(0)$ & 2.351 \\
\hline 19 & $55(0)$ & $3(-1)$ & $150(0)$ & $20(0)$ & 1.938 \\
\hline 20 & $55(0)$ & $7(+1)$ & $150(0)$ & $20(0)$ & 2.171 \\
\hline 21 & $55(0)$ & $5(0)$ & $100(-1)$ & $20(0)$ & 0.215 \\
\hline 22 & $55(0)$ & $5(0)$ & $150(+1)$ & $20(0)$ & 0.102 \\
\hline 23 & $55(0)$ & $5(0)$ & $150(0)$ & $16(-1)$ & 2.136 \\
\hline 24 & $55(0)$ & $5(0)$ & $150(0)$ & $24(+1)$ & 2.253 \\
\hline 25 & $55(0)$ & $5(0)$ & $150(0)$ & $20(0)$ & 2.889 \\
\hline 26 & $55(0)$ & $5(0)$ & $150(0)$ & $20(0)$ & 2.863 \\
\hline 27 & $55(0)$ & $5(0)$ & $150(0)$ & $20(0)$ & 2.899 \\
\hline 28 & $55(0)$ & $5(0)$ & $150(0)$ & $20(0)$ & 2.868 \\
\hline
\end{tabular}

$\mathrm{X}_{1}$ : temperature $\left({ }^{\circ} \mathrm{C}\right) ; \mathrm{X}_{2}$ : $[\mathrm{SCB}](\%) ; \mathrm{X}_{3}$ : [enzyme] $\left(\mathrm{U} \mathrm{g}^{-1}\right)$ and $\mathrm{X}_{4}$ : time $(\mathrm{h})$.

concentration were studied by plotting a 3-D response surface curve to determine the optimum level of each variable for maximum response. The response surface between enzyme load and the temperature is shown in Fig. 5, while the other variables were maintained constant at their central values.

It was noticed through response surface analysis that the highest glucose concentration was observed when the variable temperature was at its lowest level $\left(50^{\circ} \mathrm{C}\right.$ ) and the enzyme load (endoglucanase) was $150 \mathrm{U}$ g- 1 . With the increase in temperature and enzyme loading, there was a decrease in sugar concentration. It was observed that enzyme loads exceeding $150 \mathrm{U}$ g-1 did not improve saccharification efficiency. High enzyme loads may cause unproductive adsorption of it on cellulose fiber, thereby reducing the available surface area and, consequently, becoming a limiting factor in the hydrolysis rate (Bommarius et al., 2008). There may also be the inhibition of enzyme activity by hydrolysis products (Griggs et al., 2012). Literature reports that increasing the enzyme load on hydrolysis promotes an increase in the concentration of glucose but elevated enzyme loads lead to decreased concentration (Pandiyan et al., 2014; Zhang et al., 2012). 
Table 6

Analysis of variance (ANOVA) for the model representing glucose concentration in the hydrolysates obtained from enzymatic saccharification of pretreated sugarcane bagasse according to the face-centered $2^{4}$ factorial design.

\begin{tabular}{|c|c|c|c|c|c|}
\hline Variables & $\begin{array}{l}\text { Sum of } \\
\text { squares }\end{array}$ & $\begin{array}{l}\text { Degrees of } \\
\text { freedom }\end{array}$ & Mean square & $F$ value & $p$ value $^{\mathrm{a}}$ \\
\hline $\begin{array}{l}\text { (1) Temperature } \\
\left({ }^{\circ} \mathrm{C}\right)(\mathrm{L})\end{array}$ & 0.28968 & 1 & 0.28968 & 2.1910 & 0.1626 \\
\hline $\begin{array}{l}\text { Temperature } \\
\left({ }^{\circ} \mathrm{C}\right)(\mathrm{Q})\end{array}$ & 1.42272 & 1 & 1.42272 & 10.7608 & 0.0059 \\
\hline $\begin{array}{l}\text { (2) SCB load (\%) } \\
\text { (L) }\end{array}$ & 0.49837 & 1 & 0.49837 & 37694 & 0.0741 \\
\hline $\begin{array}{l}\text { SCB load (\%) } \\
\text { (Q) }\end{array}$ & 0.39106 & 1 & 0.39106 & 2.9578 & 0.1091 \\
\hline $\begin{array}{l}\text { (3) Enzyme load } \\
\left(\mathrm{Ug}^{-1}\right)(\mathrm{L})\end{array}$ & 0.03455 & 1 & 0.03455 & 0.2613 & 0.6178 \\
\hline $\begin{array}{l}\text { Enzyme load } \\
\quad\left(\mathrm{U} \mathrm{g}^{-1}\right)(\mathrm{Q})\end{array}$ & 13.47705 & 1 & 13.47705 & 101.9343 & 0.0000 \\
\hline (4) Time (h) (L) & 0.00343 & 1 & 0.00343 & 0.0260 & 0.8744 \\
\hline Time (h) (Q) & 0.16064 & 1 & 0.16064 & 1.2150 & 0.2903 \\
\hline $1 \mathrm{~L}$ by $2 \mathrm{~L}$ & 0.00028 & 1 & 0.00028 & 0.0021 & 0.9641 \\
\hline $1 \mathrm{~L}$ by $3 \mathrm{~L}$ & 0.00539 & 1 & 0.00539 & 0.0408 & 0.8430 \\
\hline $1 \mathrm{~L}$ by $4 \mathrm{~L}$ & 0.23106 & 1 & 0.23106 & 1.7476 & 0.2089 \\
\hline $2 \mathrm{~L}$ by $3 \mathrm{~L}$ & 0.10655 & 1 & 0.10655 & 0.8059 & 0.3856 \\
\hline $2 \mathrm{~L}$ by $4 \mathrm{~L}$ & 0.00354 & 1 & 0.00354 & 0.0267 & 0.8726 \\
\hline $3 \mathrm{~L}$ by $4 \mathrm{~L}$ & 0.00264 & 1 & 0.00264 & 0.0200 & 0.8897 \\
\hline Error & 1.71877 & 13 & 0.13221 & & \\
\hline $\begin{array}{c}\text { Total sum of } \\
\text { squares }\end{array}$ & 35.96028 & 27 & & & \\
\hline
\end{tabular}

$p$ values highlighted in bold are statistically significant for a confidence level of $95 \%(\mathrm{p}<0.05)$.

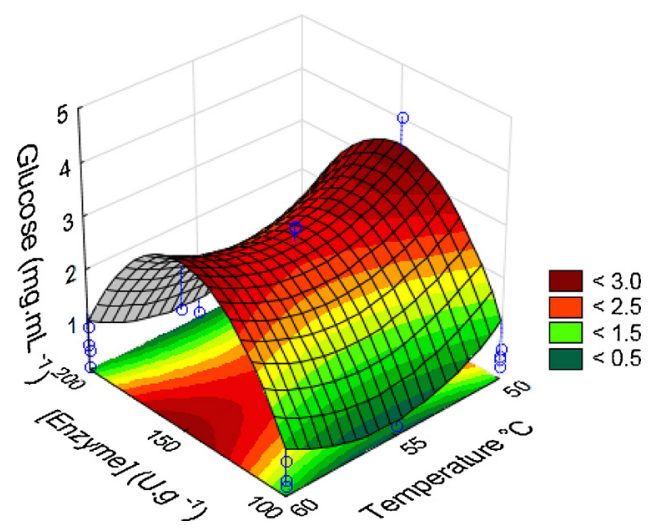

Fig. 5. Response surface described by the model that represents the conversion of cellulose to glucose (mg.mL ${ }^{-1}$ ) as a function of enzyme load and temperature.

The predicted optimum conditions for the highest saccharification from the experimental design, calculated with the desirability function (Statistica 10.0), were temperature at $50^{\circ} \mathrm{C}$, SCB load of $5 \%, 150 \mathrm{U} \mathrm{g}^{-1}$ of enzyme load and $20 \mathrm{~h}$, with maximum glucose and xylose concentrations of 3.48 and $1.54 \mathrm{mg} \mathrm{mL}^{-1}$, respectively. For model validation, three saccharification experiments were performed under the predicted optimum conditions, glucose and xylose concentrations in the hydrolysates were $3.56 \pm 0.08$ and $1.66 \pm 0.11 \mathrm{mg} \mathrm{mL}^{-1}$, respectively, indicating that the model proposed has successfully modeled the saccharification of pretreated sugarcane bagasse in the present study. Glucose and xylose concentrations obtained in the present study were close to those cited by Pereira et al. (2016) in the saccharification of ozonated sugarcane bagasse using the commercial enzymes Celluclast $1.5 \mathrm{~L}$ and Novozym 188 or the enzymatic extract from Miceliophthora thermophila JCP 1-4. Maitan-Alfenas et al. (2016) and Qu et al. (2017) also cited similar xylose concentrations in the hydrolysates obtained at approximately $24 \mathrm{~h}$ of saccharification of sugarcane bagasse submitted to alkaline pretreatment, using commercial enzymes.

\section{Conclusions}

All the evaluated endophytic fungi are potential producers of cellulases and xylanases by SSF when using lignocellulosic materials as substrates. The use of different lignocellulosic materials as substrates for SSF was important since some of them markedly induced enzymes productions by some of the fungi used in this study. Botryosphaeria sp. AM01 and Saccharicola sp. EJC04 were the most versatile regarding the production of all the enzymes evaluated, and the mixture of cotton seed meal and wheat bran as substrates significantly induced cellulases production by both fungi. This is an interesting finding, since both genera are not among those commonly cited in studies involving quantitative analysis of these enzymes production, mainly by solid state fermentation. The evaluation of different culture conditions for enzymes production was important since endoglucanase activities were increased approximately 12 and 95\%, for Botryosphaeria sp. AM01 and Saccharicola sp. EJC 04, respectively. $\beta$-glucosidase activities for these fungi were also increased, around 30 and $32 \%$, respectively. The physico-chemical characteristics of the cellulases and xylanases produced by both fungi are suitable for application in the saccharification of pretreated sugarcane bagasse and the use of the enzymes blend and experimental design for saccharification was an interesting strategy, since glucose and xylose concentrations obtained in the hydrolysates are close to some reported in scientific literature. Thus, the results obtained from the present study encourage further studies regarding saccharification of pretreated sugarcane bagasse, involving the influence of other parameters, with the objective of using hydrolysates as glucose and/or xylose source for second generation ethanol production.

\section{Acknowledgments}

This study was supported by "Fundação de Amparo à Pesquisa do Estado de São Paulo - FAPESP”, Brazil (Process number 2010/126240 ). The authors also thank "Coordenação de Aperfeiçoamento de Pessoal de Nível Superior - CAPES, Ministério da Educação", Brazil for Natalia Paganini Marques and Josiani de Cassia Pereira Master's Degree Scholarships.

\section{References}

Acharya, P., Acharya, D., Modi, H., 2008. Optimization for cellulase production by Aspergillus niger using saw dust as substrate. Afr. J. Biotechnol. 7, 4147-4152. http:// dx.doi.org/10.5897/AJB08.689.

Almeida, M.N., Guimarães, V.M., Bischoff, K.M., Falkoski, D.L., Pereira, O.L., Gonçalves, D.S.P.O., De Rezende, S.T., 2011. Cellulases and hemicellulases from endophytic Acremonium species and its application on sugarcane bagasse hydrolysis. Appl. Biochem. Biotechnol. 165, 594-610. http://dx.doi.org/10.1007/s12010-011-9278-z.

Amirita, A., Sindhu, P., Swetha, J., Vasanthi, N.S., Kannan, K.P., 2012. Enumeration of endophytic fungi from medicinal plants and screeening of extracellular enzymes. World J. Sci. Technol. 2, 13-19.

Bansal, N., Tewari, R., Soni, R., Soni, S.K., 2012. Production of cellulases from Aspergillus niger NS-2 in solid state fermentation on agricultural and kitchen waste residues. Waste Manage. 32, 1341-1346. http://dx.doi.org/10.1016/j.wasman.2012.03.006.

Barbagallo, R.N., Spagna, G., Palmeri, R., Restuccia, C., Giudici, P., 2004. Selection, characterization and comparison of $\beta$-glucosidase from mould and yeasts employable for enological applications. Enzyme Microb. Technol. 35, 58-66. http://dx.doi.org/ 10.1016/j.enzmictec.2004.03.005.

Bommarius, A.S., Katona, A., Cheben, S.E., Patel, A.S., Ragauskas, A.J., Knudson, K., Pu, Y., 2008. Cellulase kinetics as a function of cellulose pretreatment. Metab. Eng. 10, 370-381. http://dx.doi.org/10.1016/j.ymben.2008.06.008.

Cassia Pereira, J., Paganini Marques, N., Rodrigues, A., Brito de Oliveira, T., da Silva Boscolo, M.R., Gomes, E., Bocchini Martins, D.A., 2015. Thermophilic fungi as new sources for production of cellulases and xylanases with potential use in sugarcane bagasse saccharification. J. Appl. Microbiol. 118, 928-939. http://dx.doi.org/10. 1111/jam. 12757.

Chapla, V.M., Zeraik, M.L., Leptokarydis, I.H., Silva, G.H., Bolzani, V.S., Young, M.C.M., Pfenning, L.H., Araújo, A.R., 2014. Antifungal compounds produced by Colletotrichum gloeosporioides, an endophytic fungus from Michelia champaca. Molecules 19, 19243-19252. http://dx.doi.org/10.3390/molecules191119243.

Corrêa, R.C.G., Rhoden, S.A., Mota, T.R., Azevedo, J.L., Pamphile, J.A., de Souza, C.G.M., Polizeli, M.D.L.T.D.M., Bracht, A., Peralta, R.M., 2014. Endophytic fungi: expanding the arsenal of industrial enzyme producers. J. Ind. Microbiol. Biotechnol. 41, 1467-1478. http://dx.doi.org/10.1007/s10295-014-1496-2. 
de Oliveira, S.L.R., Maciel, T.C., de O. Sancho, S., Rodrigues, S., 2016. Solid-state production of cellulase by Melanoporia sp. CCT 7736: a new strain isolated from coconut shell (Cocos nucifera L.). Bioresour. Bioprocess 3, 9. http://dx.doi.org/10.1186/ s40643-016-0086-8.

Damaso, M.C.T., da C. Terzi, S., Farias, A.X., Oliveira, A.C.P., de Fraga, M.E., Couri, S., 2012. Selection of cellulolytic fungi isolated from diverse substrates. Braz. Arch. Biol. Technol. 55, 513-520. http://dx.doi.org/10.1590/S1516-89132012000400005.

Dashtban, M., Maki, M., Leung, K.T., Mao, C., Qin, W., 2010. Cellulase activities in biomass conversion: measurement methods and comparison. Crit. Rev. Biotechnol. 30, 302-309. http://dx.doi.org/10.3109/07388551.2010.490938.

Delabona, P.D.S., Pirota, R.D.P.B., Codima, C.A., Tremacoldi, C.R., Rodrigues, A., Farinas, C.S., 2013. Effect of initial moisture content on two Amazon rainforest Aspergillus strains cultivated on agro-industrial residues: biomass-degrading enzymes production and characterization. Ind. Crops Prod. 42, 236-242.

Delabona, P.D.S., 2011. Bioprospecção de fungos produtores de celulases da região amazônica para a produção de etanol celulósico. 10.1016/j.biombioe.2011.12.006

Duangwang, S., Ruengpeerakul, T., Cheirsilp, B., Yamsaengsung, R., Sangwichien, C. 2016. Pilot-scale steam explosion for xylose production from oil palm empty fruit bunches and the use of xylose for ethanol production. Bioresour. Technol. 203, 252-258. http://dx doi.org/10.1016/j.biortech.2015.12.065.

Farinas, C.S., Lemo, V., Rodríguez-Zúñiga, U.F., Neto, V.B., Couri, S., 2008. Avaliação de diferentes resíduos agroindustriais como substratos para a produção de celulases por fermentação semi-sólida. Embrapa Instrumentação Agropecuária. Bol. Pesqui. e Desenvolv 13p.

Ghose, T.K., 1987. Measurement of cellulase activities. Pure Appl. Chem. 59, 257-268. http://dx.doi.org/10.1351/pac198759020257.

Ghoshal, G., Basu, S., Shivhare, U., 2012. Solid state fermentation in food processing. Int. J. Food Eng. 8, 25. http://dx.doi.org/10.1515/1556-3758.1246.

Goswami, G.K., Rawat, S., 2015. Microbial xylanase and their applications-a review. Int. J. Curr. Res. Acad. Rev. 3, 436-450.

Griggs, A.J., Stickel, J.J., Lischeske, J.J., 2012. A mechanistic model for enzymatic saccharification of cellulose using continuous distribution kinetics II: cooperative enzyme action, solution kinetics, and product inhibition. Biotechnol. Bioeng. 109, 676-685. http://dx.doi.org/10.1002/bit.23354.

Guimarães, L.H.S., Peixoto-Nogueira, S.C., Michelin, M., Rizzatti, A.C.S., Sandrim, V.C., Zanoelo, F.F., Aquino, A.C.M.M., Junior, A.B., Polizeli, M.D.L.T.M., 2006. Screening of filamentous fungi for production of enzymes of biotechnological interest. Braz. J. Microbiol. 37, 474-480. http://dx.doi.org/10.1590/S1517-83822006000400014.

Hansen, G.H., Lübeck, M., Frisvad, J.C., Lübeck, P.S., Andersen, B., 2015. Production of cellulolytic enzymes from ascomycetes: comparison of solid state and submerged fermentation. Process Biochem. 50, 1327-1341. http://dx.doi.org/10.1016/j. procbio.2015.05.017.

Harris, P.V., Xu, F., Kreel, N.E., Kang, C., Fukuyama, S., 2014. New enzyme insights drive advances in commercial ethanol production. Curr. Opin. Chem. Biol. 19, 162-170.

Juturu, V., Wu, J.C., 2014. Microbial cellulases: engineering, production and applications. Renew. Sustain. Energy Rev. 33, 188-203. http://dx.doi.org/10.1016/j.rser.2014.01. 077.

Kalim, B., Böhringer, N., Ali, N., Schäberle, T., 2015. Xylanases from microbial origin to industrial application. Br. Biotechnol. J. 7, 1-20. http://dx.doi.org/10.9734/BBJ/ 2015/15982.

Kang, S.W., Park, Y.S., Lee, J.S., Hong, S.I., Kim, S.W., 2004. Production of cellulases and hemicellulases by Aspergillus niger KK2 from lignocellulosic biomass. Bioresour. Technol. 91, 153-156. http://dx.doi.org/10.1016/S0960-8524(03)00172-X.

Karmakar, M., Ray, R.R., 2010. Extra cellular endoglucanase production by Rhizopus oryzae in solid and liquid state fermentation of agro wastes. Asian J. Biotechnol. 2, 27-36.

Katoch, M., Salgotra, A., Singh, G., 2014. Endophytic fungi found in association with Bacopa monnieri as potential producers of industrial enzymes and antimicrobial bioactive compounds. Braz. Arch. Biol. Technol. 57, 714-722. http://dx.doi.org/10. 1590/S1516-8913201402502.

Kogel, K.H., Franken, P., Hückelhoven, R., 2006. Endophyte or parasite-what decides? Curr. Opin. Plant Biol. 9, 358-363. http://dx.doi.org/10.1016/j.pbi.2006.05.001.

Krisch, J., Bencsik, O., Papp, T., Vágvölgyi, C., Takó, M., 2012. Characterization of a $\beta$ glucosidase with transgalactosylation capacity from the zygomycete Rhizomucor miehei. Bioresour. Technol. 114, 555-560. http://dx.doi.org/10.1016/j.biortech. 2012.02.117.

Kuhad, R.C., Gupta, R., Singh, A., 2011. Microbial cellulases and their industrial applications. Enzyme Res. 2011, 280696. http://dx.doi.org/10.4061/2011/280696.

Kuusk, S., Väljamäe, P., 2017. When substrate inhibits and inhibitor activates: implications of $\beta$ - glucosidases. Biotechnol. Biofuels 10, 7. http://dx.doi.org/10.1186/ s13068-016-0690-z.

Leite, R.S.R., Alves Prado, H.F., Cabral, H., Pagnocca, F.C., Gomes, E., Da Silva, R., 2008. Production and characteristics comparison of crude $\beta$-glucosidases produced by microorganisms Thermoascus aurantiacus e Aureobasidium pullulans in agricultural wastes. Enzyme Microb. Technol. 43, 391-395. http://dx.doi.org/10.1016/j. enzmictec. 2008.07.006.

Liang, X., Huang, Y., Hua, D., Zhang, J., Xu, H., Li, Y., Zhang, X., 2012. Cellulase production by Aspergillus sp. on rice grass (Spartina spp.) under solid-state fermentation. Afr. J. Microbiol. Res. 6, 6785-6792. http://dx.doi.org/10.5897/AJMR12.986.

Maitan-Alfenas, G.P., Oliveira, M.B., Nagem, R.A.P., de Vriesb, R.P., Guimarães, V.M., 2016. Characterization and biotechnological application of recombinantxylanases from Aspergillus nidulans. Int. J. Biol. Macromol. 91, 60-67.

Mangalanayaki, R., Madhavan, S., 2015. Cellulase production by Trichoderma harzianum and Fusarium oxysporum under solid state fermentation. World J. Pharm. Pharm. Sci. 4 (11), 1822-1828.

Maurya, D.P., Singh, D., Pratap, D., Maurya, J.P., 2012. Optimization of solid state fermentation conditions for the production of cellulase by Trichoderma reesei. J. Environ. Biol. 33, 5-8.

Merheb-Dini, C., Gomes, E., Boscolo, M., da Silva, R., 2010. Production and characterization of a milk-clotting protease in the crude enzymatic extract from the newly isolated Thermomucor indicae-seudaticae N31. (Milk-clotting protease from the newly isolated Thermomucor indicae-seudaticae N31). Food Chem. 120, 87-93. http://dx. doi.org/10.1016/j.foodchem.2009.09.075.

Moreira, L.R.S., Filho, E.X.F., 2016. Insights into the mechanism of enzymatic hydrolysis of xylan. Appl. Microbiol. Biotechnol. 100, 5205-5214. http://dx.doi.org/10.1007/ s00253-016-7555-z.

Moretti, M.M.S., Bocchini-Martins, D.A., Da-Silva, R., Rodrigues, A., Sette, L., Gomes, E., 2012. Selection of thermophilic and thermotolerant fungi for the production of cellulases and xylanases under solid-state fermentation. Braz. J. Microbiol. 106, 2-1071.

Moretti, M.M.D.S., Bonfa, E.C., Chierotti, M.C.M., Movio, A.P., da Silva, R., Gomes, E., 2014. Fibrolytic enzyme production of Myceliophthora thermophila M.7.7. using inexpensive carbon sources and mineral nutrients. Afr. J. Microbiol. Res. 8, 4013-4019. http://dx.doi.org/10.1016/j.foodchem.2009.09.075.

Muthezhilan, R., Ashok, R., Jayalakshmi, S., 2007. Production and optimization of thermostable alkaline xylanase by Penicillium oxalicum in solid state fermentation. Afr. J. Microbiol. Res. 1, 20-28.

Nguyen, Q.A., Yang, J., Bae, H.J., 2017. Bioethanol production from individual and mixed agricultural biomass residues. Ind. Crops Prod. 95, 718-725.

Nigam, P.S., 2013. Microbial enzymes with special characteristics for biotechnological applications. Biomolecules 3, 597-611. http://dx.doi.org/10.3390/biom3030597.

Novy, V., Longus, K., Nidetzky, B., 2015. From wheat straw to bioethanol: integrative analysis of a separate hydrolysis and co-fermentation process with implemented enzyme production. Biotechnol. Biofuels 8, 1-12. http://dx.doi.org/10.1186/ s13068-015-0232-0.

Onofre, S.B., Silva, G.C., Mattiello, S.P., Groth, D., Malagi, I., 2013. Production of cellulolytic enzymes by Aspergillus flavus using solid state fermentation based on sugarcane bagasse. Am. J. Biochem. 3, 25-28. http://dx.doi.org/10.5923/j.ajb. 20130302.01.

Pandiyan, K., Tiwari, R., Singh, S., Nain, P.K.S., Rana, S., Arora, A., Singh, S.B., Nain, L., 2014. Optimization of enzymatic saccharification of alkali pretreated Parthenium sp. using response surface methodology. Enzyme Res. 2014, 1-8. http://dx.doi.org/10. $1155 / 2014 / 764898$.

Pemberton, M., Brown, R., Emert, G., 1980. The role of $\beta$-glucosidase in the bioconversion of cellulose to ethanol. Can. J. Chem. Eng. 58, 723-729.

Pereira, J.C., Marques, N.P., Rodrigues, A., Brito de Oliveira, T., Boscolo, M., da Silva, R., Gomes, E., Bocchini Martins, D.A., 2015. Thermophilic fungi as new sources for production of cellulases and xylanases with potential use in sugarcane bagasse saccharification. J. Appl. Microbiol. 118 (4), 928-939.

Pereira, J., de, C., Travaini, R., Marques, N.P., Bolado-Rodríguez, S., Martins, D.A.B., 2016. Saccharification of ozonated sugarcane bagasse using enzymes from Myceliophthora thermophila JCP 1-4 for sugars release and ethanol production. Bioresour. Technol. 204, 122-129. http://dx.doi.org/10.1016/j.biortech.2015.12. 064.

Qu, X., Hu, B., Zhu, M., 2017. Enhanced saccharification of cellulose and sugarcane bagasse by Clostridium thermocellum cultures with Triton X-100 and b-glucosidase/ Cellic ${ }^{\circ}$ CTec2 supplementation. RSC Adv. 7, 21360-21365.

Radecka, D., Mukherjee, V., Mateo, R.Q., Stojiljkovic, M., Foulquié-Moreno, M.R., Thevelein, J.M., 2015. Looking beyond Saccharomyces: the potential of non-conventional yeast species for desirable traits in bioethanol fermentation. FEMS Yeast Res. 15, 1-13. http://dx.doi.org/10.1093/femsyr/fov053.

Raj, K., Krishnan, C., 2018. High sugar yields from sugarcane (Saccharum officinarum) bagasse using low-temperature aqueous ammonia pretreatment and laccase-mediator assisted enzymatic hydrolysis. Ind. Crops Prod. 111, 673-683.

Rodríguez-Zúñiga, U.F., Farinas, C.S., Neto, V.B., Couri, S., Crestana, S., 2011. Produção de celulases por Aspergillus niger por fermentação em estado sólido. Pesqui. Agropecu. Bras. 46, 912-919. http://dx.doi.org/10.1590/S0100-204X2011000800018.

Sluiter, A., Hames, B., Ruiz, R., Scarlata, C., Sluiter, J., Templeton, D., Nrel, D.C., 2008. Determination of Structural Carbohydrates and Lignin in Biomass Determination of Structural Carbohydrates and Lignin in Biomass (LAP). NREL National Renewable Energy Laboratory.

Song, J.M., Wei, D.Z., 2010. Production and characterization of cellulases and xylanases of Cellulosimicrobium cellulans grown in pretreated and extracted bagasse and minimal nutrient medium M9. Biomass Bioenergy 34, 1930-1934. http://dx.doi.org/10. 1016/j.biombioe.2010.08.010.

Sun, Y., Cheng, J., 2002. Hydrolysis of lignocellulosic materials for ethanol production: a review. Bioresour. Technol. 83, 1-11. http://dx.doi.org/10.1016/S0960-8524(01) 00212-7.

Sunitha, V.H., Devi, D.N., Srinivas, C., 2013. Extracellular enzymatic activity of endophytic fungal strains isolated from medicinal plants. World J. Agric. Sci. 9, 1-9. http://dx.doi.org/10.5829/idosi.wjas.2013.9.1.72148.

Villena, M.A., Iranzo, J.F.U., Gundllapalli, S.B., Otero, R.R.C., Briones Perez, Ana I., 2006 Characterization of an exocellular $\beta$-glucosidase from Debaryomyces pseudopolymorphus. Enzyme Microb. Technol. 39, 229-234. http://dx.doi.org/10.1016/j.enzmictec. 2005.10.018.

Wipusaree, N., Sihanonth, P., Piapukiew, J., Sangvanich, P., Karnchanatat, A., 2011. Purification and characterization of a xylanase from the endophytic fungus Alternaria alternata isolated from the Thai medicinal plant, Croton oblongifolius Roxb. Afr. J. Microbiol. Res. 5, 5697-5712. http://dx.doi.org/10.5897/AJMR11.1037.

Xu, X., Lin, M., Zang, Q., Shi, S., 2018. Solid state bioconversion of lignocellulosic residues by Inonotus obliquus for production of cellulolytic enzymes and saccharification. Biores. Technol. 247, 88-95.

Yadav, P.R., Chauhan, P.B., Gahlout, M., 2016. Isolation, screening and optimization of 
process parameters for enhanced production of cellulase by solid state fermentation. Int. J. Adv. Res. Biol. Sci. 3, 21-27 1.15/ijarbs-2016-3-5-4.

Yoon, L.W., Ang, T.N., Ngoh, G.C., Seak, A., Chua, M., 2014. Fungal solid-state fermentation and various methods of enhancement in cellulase production. Biomass Bioenergy 67, 319-338. http://dx.doi.org/10.1016/j.biombioe.2014.05.013.

Zhang, H., Sang, Q., 2012. Statistical optimization of cellulases production by Penicillium chrysogenum QML-2 under solid-state fermentation and primary application to chitosan hydrolysis. World J. Microbiol. Biotechnol. 28, 1163-1174. http://dx.doi.org/ 10.1007/s11274-011-0919-8.

Zhang, Y., Liu, Y.-Y., Xu, J.-L., Yuan, Z.-H., Zhuang, X.-S., 2012. High solid and low enzyme loading based saccharification of agricultural biomass. Bioresour. Technol. 7, 345-353. http://dx.doi.org/10.15376/biores.7.1.0345-0353.

Zilly, A., dos S. Bazanella, G.C., Helm, C.V., de S. Bracht, C.A.V.A.C.G.M., Bracht, A., Peralta, R.M., 2012. Solid-state bioconversion of passion fruit waste by white-rot fungi for production of oxidative and hydrolytic enzymes. Food Bioprocess Technol. 5, 1573-1580. http://dx.doi.org/10.1007/s11947-011-0532-8. 